\title{
A new method for the preparation of artificial factor II reagents from normal human and bovine plasma
}

Citation for published version (APA):

Vermeer, C., Soute, B. A. M., \& Hemker, H. C. (1977). A new method for the preparation of artificial factor II reagents from normal human and bovine plasma. Thrombosis Research, 10(3), 495-507. https://doi.org/10.1016/0049-3848(77)90159-1

Document status and date:

Published: 01/03/1977

DOI:

10.1016/0049-3848(77)90159-1

Document Version:

Publisher's PDF, also known as Version of record

\section{Please check the document version of this publication:}

- A submitted manuscript is the version of the article upon submission and before peer-review. There can be important differences between the submitted version and the official published version of record.

People interested in the research are advised to contact the author for the final version of the publication, or visit the DOI to the publisher's website.

- The final author version and the galley proof are versions of the publication after peer review.

- The final published version features the final layout of the paper including the volume, issue and page numbers.

Link to publication

\footnotetext{
General rights rights.

- You may freely distribute the URL identifying the publication in the public portal. please follow below link for the End User Agreement:

www.umlib.nl/taverne-license

Take down policy

If you believe that this document breaches copyright please contact us at:

repository@maastrichtuniversity.nl

providing details and we will investigate your claim.
}

Copyright and moral rights for the publications made accessible in the public portal are retained by the authors and/or other copyright owners and it is a condition of accessing publications that users recognise and abide by the legal requirements associated with these

- Users may download and print one copy of any publication from the public portal for the purpose of private study or research.

- You may not further distribute the material or use it for any profit-making activity or commercial gain

If the publication is distributed under the terms of Article $25 \mathrm{fa}$ of the Dutch Copyright Act, indicated by the "Taverne" license above, 
THROMBOSIS RESEARCH Volume 10, Pages 495-507. Pergamon Press, 1977. Printed in Gt. Britain.

A NEW METHOD FOR THE PREPARATION OF ARTIFICIAL FACTOR II REAGENTS FROM NORMAL HUMAN AND BOVINE PLASMA

C. Vermeer, B.A.M. Soute and H.C. Hemker

Department of Biochemistry, State University

Limburg, Maastricht, The Netherlands.

(Received 28.6.1976. Accepted by Editor F. Josso.

Received by Executive Editorial Office 28.1.1977)

ABSTRACT

An artificial factor II reagent is composed by supplementing $\mathrm{BaSO}_{4}$ adsorbed plasma with a concentrated solution, containing factors VII and $\mathrm{X}$. These factors are prepared by the addition of Echis Carinatus venom to plasma, removal of the clot which has formed within 1 hour, adsorption of the factors VII and X to DEAE Sephadex, followed by a step elution and subsequent dialysis of the factors. The reagent contains no detectable Echis Carinatus venom, factor II or thrombin. The advantages of this reagent over the conventional ones are discussed.

\section{INTRODUCTION}

For the determination of coagulation factor II generally two procedures are used:

a. The one-stage assay in which factor II deficient plasma and thromboplastin constitute a medium in which all factors except prothrombin are present in excess.The prothrombin content of the sample added is rate limiting. The clotting time upon recalcification thus indicates the prothrombin level (1).

b. The two-stage assay in which first the prothrombin present in the sample is converted into thrombin. In a second stage the thrombin content is 
assessed by measuring the clotting time with a suitable source of fibrinogen (2).

The disadvantage of the first method is that both artificial and congenital factor II deficient plasmas usually contain residual amounts of prothrombin so that in the absence of added prothrombin still a rather short coagulation time is scored, consequently low prothrombin concentrations are difficult to assess. The two-stage method although more elaborate than the one-stage assay is especially useful in the determination of more or less purified factor II preparations. In plasma and plasma dilutions, however, the assay is hampered by the presence of thrombin inhibitors such as antithrombin, which necessitates evaluation of the time-course of thrombin generation and breakdown $(3,4)$.Moreover, the two-stage procedure slowly generates thrombin activity from abnormal prothrombin to an extend depending on the prevailing conditions (4).

In this paper we describe the preparation of an artificial reagent for the one-stage determination of bovine as well as human factor II. The reagent may be prepared in one day and is virtually free of factor II.

\section{MATERIALS AND METHODS}

Buffers: Buffer A $0.15 \mathrm{M} \mathrm{NaC1}, 0.005 \mathrm{M}$ Tris-HC1, $\mathrm{pH} 7.0$.

Buffer B $1.0 \mathrm{M} \mathrm{NaCl}, 0.005 \mathrm{M}$ Tris-HC1, $\mathrm{pH} 7.0$.

Buffer C 0.0286 M Sodium acetate, 0.0286 M Sodium barbiturate, $0.1164 \mathrm{M} \mathrm{NaCl}$. The $\mathrm{pH}$ was adjusted with $1.0 \mathrm{M} \mathrm{HCl}$ to 7.4 .

Buffer D 0.0143 M Sodium acetate, 0.0143 M Sodium barbiturate, $0.0582 \mathrm{M} \mathrm{NaCl}$. The $\mathrm{pH}$ was adjusted with $1.0 \mathrm{M} \mathrm{HCl}$ to 7.4 .

Buffer E $0.04 \mathrm{M}$ Disodium oxalate, $0.06 \mathrm{M}$ Trisodium citrate. The $\mathrm{pH}$ was adjusted with $1.0 \mathrm{M} \mathrm{HCl}$ to 7.0 .

Buffer F $0.06 \mathrm{M}$ Trisodium citrate, $0.05 \mathrm{M}$ Tris-HC1, $\mathrm{pH} 7.1$. ACD-plasma: human ACD plasma was prepared as described in ref. 5. Normal pool plasma:human reference plasma was prepared as described in ref. 6 . Bovine reference plasma was prepared in a similar way from 30 cows. The procoagulant activity of each factor in these standards was arbitrarily considered to be $100 \%=1 \mathrm{U} / \mathrm{ml}$.

Coagulation tests: Coagulation tests were performed as described in ref.6. Reagents were prepared according to ref. 7 (factor V) and ref. 6 (factors VII and $\mathrm{X}$ ).

Human thromboplastin and reagents prepared from human plasma were used, when human clotting factors and bovine factor $V$ were assayed. Bovine thromboplastin and reagents prepared from bovine plasma were used when bovine factors II,VII, and $\mathrm{X}$ were assayed. Fibrinogen was assayed according to ref. 8 . 
Echis Carinatus venom assay for factor II: five $\mu l$ of a solution of Echis Carinatus venom in buffer $\mathrm{C}(2 \mathrm{mg} / \mathrm{ml})$ were supplemented with $0.1 \mathrm{ml}$ sample and $0.1 \mathrm{ml} \mathrm{CaC1}{ }_{2}(1 / 30 \mathrm{M})$ and incubated for $10 \mathrm{~min}$ at $37^{\circ} \mathrm{C}$ in a Depex coagulometer. The coagulation was started by the addition of $0.2 \mathrm{ml}$ of bovine fibrinogen solution (see below).

Preparation of bovine factor II reagent (B): Bovine blood was collected in 0.1 M disodium oxalate $(10 \% \mathrm{v} / \mathrm{v})$ and the plasma was separated from the "packed cells" by centrifugation ( $2 \times 30 \mathrm{~min}$ at 4,000xg).

a. Five hundred $\mathrm{ml}$ of plasma were three times adsorbed with $\mathrm{BaSO}_{4}(100 \mathrm{mg} / \mathrm{m} 1)$. After each adsorption step the plasma was centrifuged for $10 \mathrm{~min}$ at 4,000 $\mathrm{x}$ $\mathrm{g}$ and finally for $30 \mathrm{~min}$ at $30,000 \mathrm{xg}$. This plasma was used as a source for fibrinogen and factor $V$. The factor $V$ content of the plasma was $56 \%$.

b. While stirring, 31 of plasma were supplemented with $45 \mathrm{ml} 1 \mathrm{M} \mathrm{CaCl}_{2}$ and $3 \mathrm{mg}$ Echis Carinatus venom (Sigma). After incubation for $2 \mathrm{~h}$ at $37^{\circ} \mathrm{C}$ the clot was disrupted and removed by centrifugation ( $1 \mathrm{~h}, 4,000 \mathrm{xg})$. The supernatant was supplemented with $50 \mathrm{ml}$ DEAE Sephadex A 50 slurry in buffer $\mathrm{F}$, stirred for 1 hour and left for $10 \mathrm{~min}$. After decantation of the supernatant serum, the Sephadex was brought into a column $(2 \times 30 \mathrm{~cm})$ and washed with 11 of buffer A. In contrast to the factors VII and X Echis Carinatus venom does not adsorb onto the Sephadex under these conditions (9) and it was completely removed by this washing procedure.

The presence of Echis Carinatus venom was detected in the first fractions by taking $0.1 \mathrm{ml}$ aliquots which were supplemented with $0.1 \mathrm{ml} \mathrm{CaCl}{ }_{2}(1 / 30 \mathrm{M})$ and $0.1 \mathrm{ml}$ normal plasma and subsequently incubated at $37^{\circ} \mathrm{C}$. Fractions containing the venom showed a clot formation within $5 \mathrm{~min}$. The factors VII and $\mathrm{X}$ were eluted from the column by a step elution with buffer B. The recovery of factor $\mathrm{X}$ was $55 \%$. That of factor VII > 100\%, showing that this factor had been activated slightly. The fractions containing factors VII and $\mathrm{X}(40 \mathrm{ml})$ were pooled, dialyzed against buffer $\mathrm{A}$ and supplemented with the $\mathrm{BaSO}_{4}$ adsorbed plasma (see above) in such a way that factor $X \geqslant 100 \%$. The factor VII content was $200-300 \%$ before freezing and about $45 \%$ after freezing and thawing. Further freezing and thawing did not decrease the factor VII content. One litre of reagent was obtained from about 4 litres of plasma. The reagent was frozen in $2 \mathrm{ml}$ portions at $-80^{\circ} \mathrm{C}$.

Bovine fibrinogen preparation: Twenty litres of bovine oxalate plasma were adsorbed with $750 \mathrm{~g} \mathrm{BaSO}_{4}$, centrifuged for $30 \mathrm{~min}$ at 4,000xg and frozen at $-30^{\circ} \mathrm{C}$. Cryoprecipitate was prepared by thawing this plasma at $4^{\circ} \mathrm{C}$. The precipitate was removed from the plasma by centrifugation ( $30 \mathrm{~min}$ at $4,000 \mathrm{xg}$ ) and 
dissolved in buffer $D$ to a final volume of $750 \mathrm{ml}$. Subsequent $1 \mathrm{y}$, we adsorbed the solution twice with $75 \mathrm{~g} \mathrm{BaSO}_{4}$, once with $\mathrm{Al}(\mathrm{OH})_{3}(1 \% \mathrm{w} / \mathrm{v}, \mathrm{BDH}$ moist gel) and once with $4 \mathrm{~g}$ QAE Sephadex. After each adsorption step the adsorbent was removed from the solution by centrifugation ( $10 \mathrm{~min}$ at $4,000 \mathrm{xg})$. Finally, the solution was centrifuged for $30 \mathrm{~min}$ at $30,000 \mathrm{xg}$ and frozen in $2 \mathrm{ml}$ portions at $-80^{\circ} \mathrm{C}$.

Preparation of human factor II reagent $(\mathrm{H})$ :

a. Human blodd was collected in buffer $\mathrm{E}(10 \% \mathrm{v} / \mathrm{v})$, cooled at $9^{\circ} \mathrm{C}$ and centrifuged for $30 \mathrm{~min}$ at $4,000 \mathrm{xg}$. The plasma was siphoned off and adsorbed three times with $\mathrm{BaSO}_{4}(100 \mathrm{mg} / \mathrm{ml})$ as described for reagent $\mathrm{B}_{1}$. The factor $\mathrm{V}$ content of the plasma was $98 \%$.

b. While stirring, one litre of human ACD plasma was supplemented with $15 \mathrm{ml}$ 1. $\mathrm{M} \mathrm{CaCl} 2$ and $2 \mathrm{mg}$ Echis Carinatus venom. After incubation for 1 hour at $37^{\circ} \mathrm{C}$ the clot was disrupted and removed by centrifugation ( $1 \mathrm{~h}, 4,000 \mathrm{xg}$ ). The supernatant was diluted 10 times with distilled water, supplemented with $25 \mathrm{ml}$ QAE Sephadex slurry in buffer $\mathrm{F}$ and stirred overhight at $10^{\circ} \mathrm{C}$. This procedure was required for a good factor VII adsorption onto the Sephadex. After decantation of the supernatant serum, the Sephadex was brought into a column $(2 \times 30 \mathrm{~cm})$, washed with one litre of buffer A and eluted stepwise with buffer $B$. The recovery of factor $X$ was $53 \%$, that of (partly activated) factor VII 150\%. After that we pooled and dialyzed the factor VII and $\mathrm{X}$ containing fractions; they were supplemented with $\mathrm{BaSO}_{4}$ adsorbed plasma (see above) in such a way that factor $X \geqslant 100 \%$. One litre of reagent was obtained from 2 litres of plasma.The reagent was divided into $2 \mathrm{ml}$ portions and frozen at $-80^{\circ} \mathrm{C}$. The activated fraction of factor VII did not disappear during freezing and thawing of the reagent.

\section{$\underline{\text { RESULTS }}$}

A. The bovine reagent

Two batches of reagent $B$ were prepared and we analyzed them for their content of factors $I, I I, V, V I I$, and $X$, buffer time, and clotting time at three factor II concentrations (Table I).Before freezing of the reagent, the factors VII and X had been added in amounts of $250 \%$ and $100 \%$, respectively. As can be seen from table I, the activity of these factors decreased substantially after freezing and thawing, which should be taken into account when the reagent is composed. 


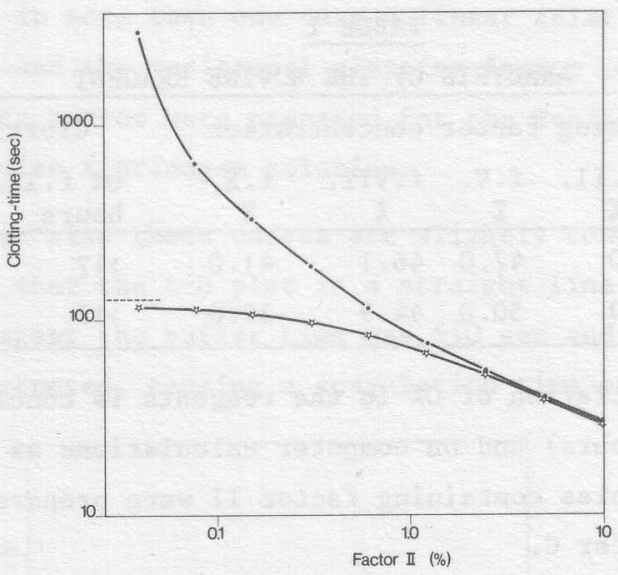

FIG.1.

Double-log plot of the reference curves for bovine factor II in the coagulation assay

- - reagent B

* - * reagent $\mathrm{B}$ to which $0.5 \%$ factor II has been added

-.--- buffer time of reagent B containing $0.5 \%$ factor II.

Up to very low factor II concentrations a linear relationship exists between the clotting time and the dilution of the reference plasma $(1 / c)$. When the reference plasma was replaced by a factor II preparation,purified according to ref. $14^{*}$, very short clotting times were measured at high factor II concentrations. For instance, the clotting time of a sample containing $200 \%$ of factor II was found to be $11.7 \mathrm{sec}$. showing that the reagent contains all other coagulation factors in sufficient amounts (fig. 2).

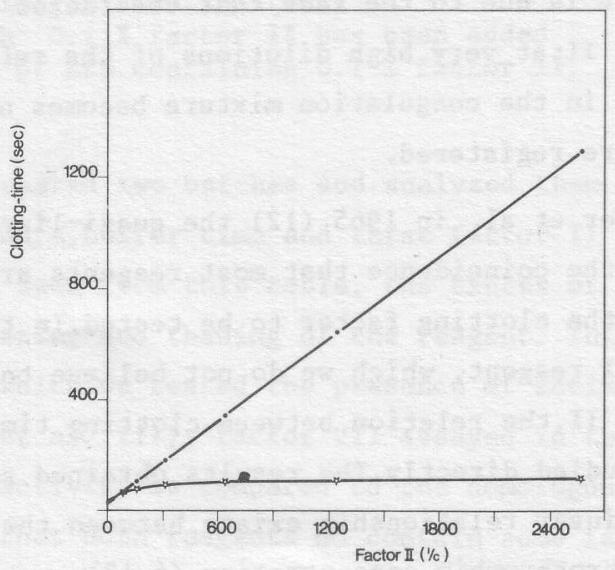

FIG. 2 .

$t-D$ plot of the reference curves for bovine factor II in the coagulation assay. Further details are described in the legend to fig. 1.

* Purified bovine factor II was kindly provided by Mrs.J.Govers-Riemslag. 
TABLE I

ANALYSIS OF THE BOVINE REAGENT

\begin{tabular}{|cccccccccc|}
\hline Batch no. & \multicolumn{3}{c|}{ Clotting factor concentration } & \multicolumn{3}{c|}{ Clotting time at } \\
& $\begin{array}{c}\text { f.I. } \\
\text { mg\% }\end{array}$ & f.II. & f.V. & f.VII. & f.X. & 0\% f.II. & 1\% f.II. & $\begin{array}{c}\text { 10\% f.II } \\
\text { sec. }\end{array}$ \\
\hline 1 & 278 & 0 & 47.0 & 46.1 & 41.0 & $>17$ & 112.2 & 30.3 \\
2 & 312 & 0 & 50.0 & 44.9 & 39.0 & $>17$ & 93.8 & 30.2 \\
\hline
\end{tabular}

The factor II concentration of $0 \%$ in the reagents is concluded from the buffer time (more than 15 hours) and on computer calculations as described in ref. 4 and ref. 10. The samples containing factor II were prepared by diluting reference plasma with buffer $C$.

Experiments in which factor VII was tested with either bovine or human thromboplastin as described by Hemker et al. (11) indicated that by freezing the activated fraction of bovine factor VII had disappeared. The partial activation of factor VII could not be prevented by the omission of $\mathrm{CaCl}_{2}$. Moreover, without $\mathrm{CaCl}_{2}$ the prothrombin was removed less efficiently.

The preparation of factor II reference curves

With the aid of reagent $B$ we tested factor II in varying dilutions of bovine normal pool plasma. When the clotting time is plotted against the factor II concentration, a convex curve is obtained on double-logarithmic scale (fig.1). Addition of small amounts of factor II to the reagent restores the sigmoid shape, which is usual for reference curves of clotting factors. Obviously, the convex form of the curve is due to the fact that the factor II reagent is absolutely free of factor II:at very high dilutions of the reference plasma the factor II concentration in the coagulation mixture becomes negligible and infinite clotting times are registered.

As was proposed by Hemker et al. in 1965 (12) the quasi-1inearity of a $\log -\mathrm{C}$ $\log t$ plot is based on the coincidence that most reagents are non-ideal, i.e. they contain traces of the clotting factor to be tested. In the case of the newly prepared factor II reagent, which we do not believe to contain even trace amounts of factor II, the relation between clotting time and prothrombin concentration can be studied directly. The results obtained seem to support the hypothesis that a linear relationship exists between the clotting time and the inverse of the prothrombin concentration $(6,13)$. 
In order to show that in more than one case a linear relationship exists between clotting time and the reciprocal clotting factor concentration ( $t-D$ plot), similar neference curves were prepared for the Echis Carinatus assay of factor II with the bovine fibrinogen solution.

Figs. 3 and 4 show that also these curves are slightly convex on double logarithmic scale and that the $t-D$ plot is a straight line. With $0.1 \%$ of prothrombin in the reagent the buffer time was $650 \mathrm{sec}$ and $0.001 \%$ of prothrombin was easily detected, causing a coagulation time of $550 \mathrm{sec}$.

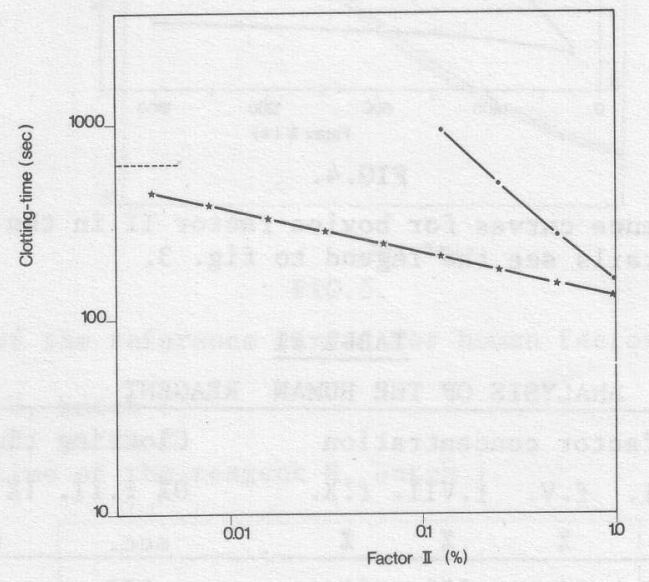

FIG. 3 .

Double-log plot of the reference curves for bovine factor II in the Echis Carinatus assay.

- - bovine fibrinogen solution (BFS)

* BFS to which $0.1 \%$ factor II has been added

- buffer time of BFS containing $0.1 \%$ factor II.

\section{B. The human reagent}

From reagent $\mathrm{H}$ we prepared two batches and analyzed them for their content of factors I, II, V,VII, and X, buffer time and three factor II concentrations (see Table II). As can be seen from this table, the excess of factor VII was not destroyed during freezing and thawing of the reagent. This was in agreement with experiments in which we tested the presence of activated factor VII according to Hemker et a1. (11): factor VII assayed in the heterologous system showed a seven-fold activity as compared to the homologous system.From Table II it is also clear that both reagents do contain some factor II activity, especially batch no. 1 . 


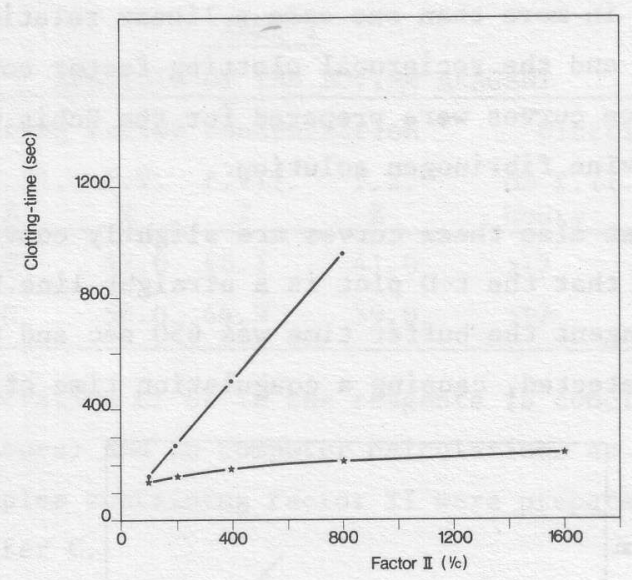

FIG. 4.

t-D plot of the reference curves for bovine factor II in the Echis Carinatus assay. For further details see the legend to fig. 3.

TABLE II

ANALYSIS OF THE HUMAN REAGENT

\begin{tabular}{|cccccccccc|}
\hline Batch no. & \multicolumn{4}{c}{ Clotting factor concentration } & \multicolumn{2}{c|}{ Clotting time at } \\
& f.I. & f.II. & f.V. & f.VII. & f.X. & 0\% f.II. & 1\% f.II. & $10 \%$ f.II. \\
& mg\% & $\%$ & $\%$ & $\%$ & $\%$ & sec. & sec. & sec. \\
\hline 1 & 233 & 0.06 & 94 & 376 & 84 & 572 & 55.8 & 18.5 \\
2 & 249 & 0.01 & 72 & 134 & 37 & 1178 & 60.7 & 19.7 \\
\hline
\end{tabular}

The factor II concentration of 0.01 in batch 2 was given by computer calculations $(4,10)$. The same holds true for the factor II concentration in batch 1 which may also be found when the buffer time of batch 1 is compared to the reference curve for batch 2 .

Possibly the adsorption of factor II onto the $\mathrm{BaSO}_{4}$ had not been complete and an additional $\mathrm{BaSO}_{4}$ adsorption step is required in order to obtain a reagent completely free of factor II.

The preparation of factor II reference curves

In a similar way as was described for the bovine system, reference curves for reagent $H$ were prepared from normal pool human plasma. The results are given in fig. 5 (double-log plot) and fig. 6 ( $t-D$ plot). The double log plot of batch 1 (containing $0.06 \%$ factor II) is convex between 10 and $0.5 \%$ factor II, then it flattens in order to become almost horizontal below factor II concentrations of $0.02 \%$. The double log plot of batch 2 (containing $0.01 \%$ 
factor II) is convex, at least between 10 and $0.04 \%$ factor II and linear for these concentrations in the $t-D$ plot. The minimal clotting time with freshly prepared purified factor II preparation amounted to $11.2 \mathrm{sec}$.

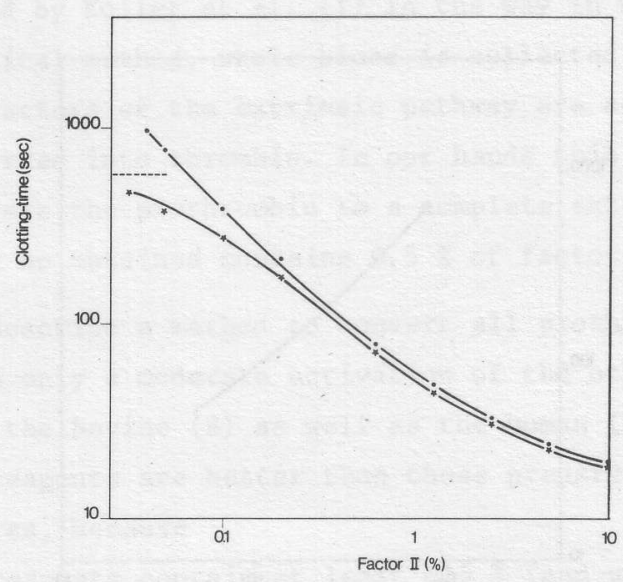

FIG. 5.

Double-log plot of the reference curves for human factor II in the coagulation assay.

* - \pm reagent $\mathrm{H}$, batch 1

- - reagent $\mathrm{H}$, batch 2

-.-- buffer time of the reagent $H$, batch 1 .

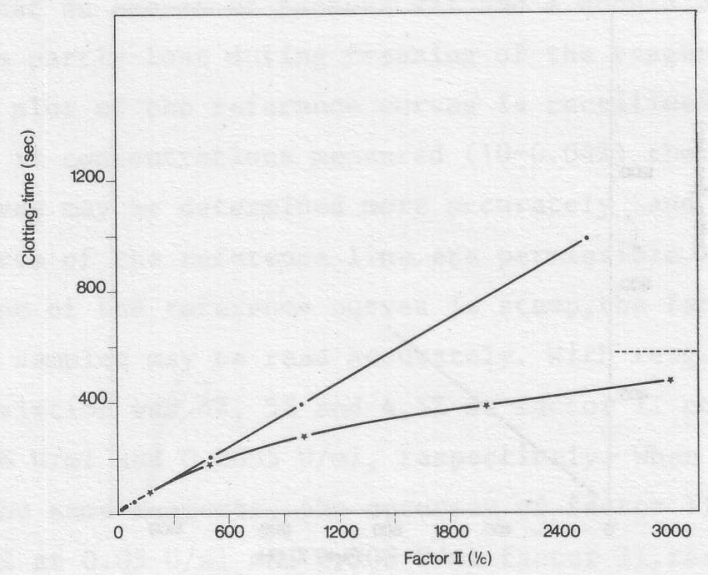

FIG. 6.

t-D plot of the reference curves for human factor II in the coagulation assay. For further details, see the legend to fig. 5 .

* Factor II was purified according to ref. 15 and was a kind gift of Mr. P.P.Devilee. 
For the Echis Carinatus assay of human factor II reference curves were prepared with the bovine fibrinogen solution (figs. 7 and 8 ). A slightly convex curve was obtained on a double-log scale (fig. 7) and a straight line in the t-D plot (fig. 8).

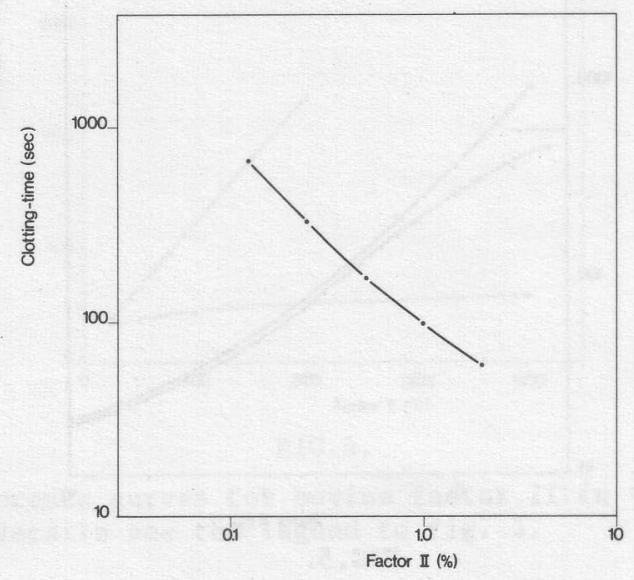

FIG. 7.

Double-log plot of the reference curve for human factor II in the Echis Carinatus assay with bovine fibrinogen solution.

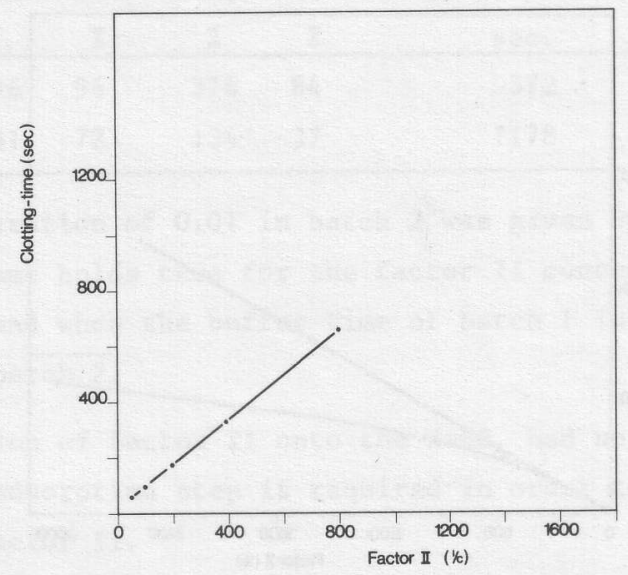

FIG. 8 .

t-D plot of the reference curve for human factor II in the Echis Carinatus assay with bovine fibrinogen solution.

\section{DISCUSSION}

With the aid of Echis Carinatus venom we were able to prepare a factor II 
reagent which did not contain any detectable factor II. The method differs from that described by Koller et a1. (1) in the way in which serum is prepared. In the classical method, whole blood is collected in thromboplastin, and at least all factors of the extrinsic pathway are activated before factor II is converted into thrombin. In our hands this system has never been able to activate the prothrombin to a complete extent and the best reagents which may be obtained contains $0.5 \%$ of factor II and usually more. In this paper we describe a method to convert all prothrombin enzymatically into thrombin with only a moderate activation of the other factors. The method is fit for the bovine (B) as well as the human (H) system. It is our opinion that the reagents are better than those prepared according to the classical procedures, because

1. The classical reagents contain at least $0.5 \%$ (and usually $1-2 \%$ ) of factor II whereas reagent $B$ and reagent $H$ contain $0 \%$ and $0.01 \%$ of factor II, respectively.

2. The factors $I, V, V I I$, and $X$ may be added to the reagents $B$ and $H$ in higher concentrations as compared to the classical reagents. It should be noticed however, that an excess of factors VII and $\mathrm{X}$ should be added because these factors are partly lost during freezing of the reagent.

3. As the $t-D$ plot of the reference curves is rectilinear, at least between al1 factor II concentrations measured (10-0.04\%) the position of the reference curves may be determined more accurately and readings on extrapolated parts of the reference line are permissible.

4. As the slope of the reference curves is steep, the factor II concentration of unknown samples may be read accurately. With reagents $B$ and $H$ the maximal deviation was $4 \%, 5 \%$ and $4.5 \%$ at factor II concentrations of 0.05 $\mathrm{U} / \mathrm{ml}, 0.008 \mathrm{U} / \mathrm{ml}$ and $0.0005 \mathrm{U} / \mathrm{ml}$, respectively. When $0.5 \%$ factor II is added to the same reagents, the accuracy of factor II determinations is $5 \%$, and $10 \%$ at $0.05 \mathrm{U} / \mathrm{ml}$ and $0.008 \mathrm{U} / \mathrm{ml}$ factor II, respectively, whereas $0.0005 \mathrm{U} / \mathrm{ml}$ of factor II is indistinguishable from the buffer time.

The reference curves presented in this paper strongly support the hypothesis that a linear relationship exists between the clotting time and the inversed concentration of clotting factor and that the sigmoid form of the usual reference curves is dependent on the presence in the reagent of a certain amount of the olotting factor to be tested $(6,12,13)$. The hypothesis was proven to be correct in two cases: the factor II determination in the onestage coagulation assay with the reagents $B$ or $H$ and the determination of 
of thrombin (derived from factor II with Echis Carinatus venom) with the bovine fibrinogen solution.

Reference curves with purified thrombin also showed strongly convex curves on log-log scale and straight t-D plots (10).

of course, the only way in which the hypothesis may be proven for other factors than thrombin and factor II is the preparation of more clotting factor reagents, which do not contain small amounts of the factor to be tested and which show an infinite buffer time.

\section{REFERENCES}

1. KOLLER,F., LOELIGER,E.A., DUCKERT,F. Experiments on a new clotting factor (factor VII). Acta Haem. 6, 1-18, 1951.

2. WARE,A.G., SEEGERS,W.H. Two-stage procedure for the quantitative determination of prothrombin concentration. Am.J.Clin.Path. 19,471-482, 1949.

3. HEMKER, H. C. , HEMKER, P.W. , v. d. TORREN, K. , DEVILEE, P.P. ,HEMKER, W. Th. , LOELIGER, E.A. The evaluation of the two-stage prothrombin assay. Thrombos.Diathes. haemorrh. 25, 545-554, 1971.

4. HEMKER, H. C. , MULLER, A.D., LOELIGER, E. A. Two types of prothrombin in vitamin $\mathrm{K}$ deficiency. Thrombos.Diathes.haemorrh. 23.633-637, 1970.

5. VERMEER, C., SOUTE, B.A.M. ,ATES, G., BRUMMELHUIS, H.G.J. Contributions to the optimal use of human blood.VIII. Increase of the yield of factor VIII in four-donor cryoprecipitate by an improved processing of blood and plasma. Vox Sang. 30, 1-22, 1976.

6. HEMKER, H.C., SWART, A.C.W., ALINK, A.J.M. Artificial reagents for factor VII and $\mathrm{X}$; a computer program for obtaining reference tables for one-stage determinations in the extrinsic system. Thrombos.Diathes.haemorrh. 27, 205-211, 1972.

7. BORCHGREVINK, C.F., POOL, J.G., STORMORKEN, H. A new assay for factor V (proaccelerin-accelerin) using Russel1's Viper venom. J.Lab.C1in.Med. 55,
$625,1960$.

8. BANG,H.0. Quantitative determination of fibrinogen in plasma, Gram's method modified. Scand.J.C1in. Lab. Invest. 9, 205, 1957.

9. FRANZA, B.R., ARONSON, D. L. ,FINALYSON, J.S. Activation of human prothrombin by a procoagulant fraction from the venom of Echis Carinatus. Identification of a high molecular weight intermediate with thrombin activity. J.Biol. Chem. 250, 7057-5068, 1975.

10. GOVERS-RIEMSLAG, J. Unpublished results.

11. HEMKER, H.C., MULLER, A.D., GONGGRIJP, R. The estimation of activated human blood coagulation factor VII. J.Mol.Med. 2, 127-134, 1976. 
12. HEMKER,H.C., HEMKER,P.W., LOELIGER, E.A. Kinetic aspects of the interaction of blood clotting enzymes. I. Derivation of basic formulas. Thrombos.Diathes.haemorrh. 13, 155-175, 1965.

13. HEMKER, H.C., VERMEER, C., GOVERS-RIEMSLAG, J. In preparation.

14. OWEN, W.G.,ESMON, C.T., JACKSON, C.M. The conversion of prothrombin to thrombin. I. Characterization of the reaction products formed during the activation of bovine prothrombin. J.Biol.Chem. 249, 594-650, 1974 .

15. DEVILEE,P.P.,HEMKER,H.C.,BAS,B.M. The influence of cadmium ions on the adsorption of prothrombin onto $\mathrm{AL}(\mathrm{OH})_{3}$ as a means to purify prothrombin. Biochim. Biophys.Acta 379, 172-179, 1975. 